\title{
Tingkat Kepuasan Pasien terhadap Pelayanan Puskesmas Buka Sampai Ndalu (Posdalu) di Puskesmas Jenggot Kota Pekalongan
}

\author{
Swasti Artanti ${ }^{1}$, Hilda Prajayanti ${ }^{2}$ \\ Email : swasti.artanti@gmail.com \\ Akademi Kebidanan Harapan Ibu Pekalongan \\ Jl. Sriwijaya No 7 Kota Pekalongan \\ Telp 085102998866
}

\begin{abstract}
Abstrak
Kepuasan pasien adalah suatu tingkat perasaan pasien yang timbul sebagai akibat dari kinerja layanan kesehatan yang diperolehnya setelah pasien membandingkannya dengan apa yang diharapkannya. Puskesmas sebagai pelayanan kesehatan tingkat awal di masyarakat mempunyai wewenang dan tanggung jawab atas pemeliharan kesehatan untuk mencapai derajat kesehatan masyarakat yang setinggi- tingginya. Survei lapangan mengenai kepuasan pasien menjadi suatu masalah penting untuk diketahui hasilnya karena dapat digunakan untuk peningkatan kepuasan pasien mutu layanan kesehatan. Oleh sebab itu, pengukuran kepuasan pasien perlu dilakukan secara berkala dan akurat. Oleh karena itu, untuk mengetahui lebih jelas kondisi kepuasaan pasien di puskesmas tersebut peneliti akan melakukan survey dengan sampel yang lebih besar untuk mengetahui secara umum Tingkat Kepuasan Pasien Terhadap Pelayanan Puskesmas Buka Sampai Ndalu (Posdalu) Di Puskesmas Jenggot Kota Pekalongan. Jenis penelitian ini menggunakan pendekatan kuantitatif dengan desain deskriptif. Populasi pada penelitian ini adalah pasien di Jenggot Kota Pekalongan. Pada penelitian ini tekhnik pengambilan sampel menggunakan tekhnik Non-probability Sampling yaitu incidental sampling. Instrument dalam penelitian ini adalah dengan menggunakan kuesioner. Instrumen penelitian yang dapat diterima sesuai standar adalah instrumen yang telah melalui uji validitas dan reabilitas. Pada penelitian ini didapatkan hasil bahwa tingkat kepuasan pasien di Puskesmas Jenggot dapat dikatakan sangat memuaskan dengan persentase $52 \%$.
\end{abstract}

Kata Kunci : Kepuasan pasien, Puskesmas

\begin{abstract}
Patient satisfaction is a level of patient feeling that arises as a result of the performance of health services obtained after the patient compares it with what they expected. Puskesmas as the initial level of health services in the community have the authority and responsibility for health maintenance to achieve the highest degree of public health. The field survey on patient satisfaction is an important issue to know the results because it can be used to improve the patient satisfaction with the quality of health services. Therefore, measurement of patient satisfaction needs to be done regularly and accurately. Therefore, to find out more clearly about the condition of patient satisfaction at the puskesmas the researcher will conduct a survey with a larger sample to find out in general the Level of Patient Satisfaction with the Puskesmas Overnight Services (Posdalu) at the Jenggot Public Health Center in Pekalongan City. This type of research uses a quantitative approach with descriptive design. The population in this study were patients in Jenggot, Pekalongan City. In this study the sampling technique uses non-probability sampling technique, namely incidental sampling. The instrument in this study was using a questionnaire. Research instruments that can be accepted according to standards are instruments that have passed the validity and reliability tests. In this study the results were obtained that the level of patient satisfaction in Puskesmas (Public Health Center) Jenggot can be said to be very satisfying with a percentage of $52 \%$.
\end{abstract}

Keywords : Patient satisfaction, Puskesmas. 


\section{Pendahuluan}

Kepuasan pasien adalah suatu tingkat perasaan pasien yang timbul sebagai akibat dari kinerja layanan kesehatan yang diperolehnya setelah pasien membandingkannya dengan apa yang diharapkannya. Kepuasan pasien merupakan keluaran (outcome) layanan kesehatan. Dengan demikian, kepuasan pasien merupakan salah satu tujuan dari peningkatan mutu layanan kesehatan. Pasien baru akan merasa puas jika kinerja layanan kesehatan yang diperolehnya sama atau melebihi harapannya dan sebaliknya, ketidakpuasan atau perasaan kecewa pasien akan muncul apabila kinerja layanan kesehatan yang diperolehnya itu tidak sesuai dengan harapan yang merupakan konsep dari kepuasan. Pengukuran tingkat kepuasan pasien menjadi kegiatan yang tidak dapat dipisahkan dari pengukuran kualitas layanan kesehatan ${ }^{1]}$

Survei lapangan mengenai kepuasan pasien menjadi suatu masalah penting untuk diketahui hasilnya karena dapat digunakan untuk peningkatan kepuasan pasien mutu layanan kesehatan. Oleh sebab itu, pengukuran kepuasan pasien perlu dilakukan secara berkala dan akurat. Peningkatan pemanfaatan survei kepuasan pasien sebagai analisis yang berkesinambungan akan menghasilkan informasi baik untuk inovasi organisasi ataupun sikap personel $^{1]}$

Survey awal sebagai pendahuluan yang dilakukan di Puskesmas Jenggot Kota Pekalongan, didapatkan data bahwa kunjungan pasien yang banyak. Studi pendahuluan dilanjutkan dengan survey langsung terhadap sepuluh pasien yang telah berobat ke Puskesmas Jenggot dengan menanyakan secara langsung poin- poin pertanyaan pada kuesioner terkait dimensi tangibles, reliability, assurance dan empathy. Dua orang diantaranya mengatakan masih ada yang kurang dengan pelayanan di Puskesmas Jenggot Kota Pekalongan. Masalah yang paling sering dikeluhkan oleh pasien mengenai kurang mendapatkan informasi tentang penggunaan obat dengan jelas, ada beberapa petugas yang tidak ramah dan tidak cepat dalam merespon dan melayani pasien yang berkunjung.

Oleh karena itu, untuk mengetahui lebih jelas kondisi kepuasaan pasien di puskesmas tersebut peneliti akan melakukan survey dengan sampel yang lebih besar untuk mengetahui secara umum Tingkat Kepuasan Pasien Terhadap Pelayanan Puskesmas Buka Sampai Ndalu (Posdalu) Di Puskesmas Jenggot Kota Pekalongan.

\section{Metode Penelitian}

\begin{tabular}{lr}
\multicolumn{1}{c}{ Jenis penelitian ini } \\
menggunakan & pendekatan \\
kuantitatif dengan desain deskriptif
\end{tabular}

Tujuan penelitian ini adalah untuk memperoleh informasi tentang gambaran tingkat kepuasan pasien di Puskesmas Jenggot Kota Pekalongan.

Populasi adalah wilayah generalisasi yang terdiri atas: obyek/subyek yang mempunyai kualitas dan karakteristik tertentu yang diterapkan oleh peneliti untuk dipelajari dan kemudian ditarik kesimpulannya ${ }^{2]}$ Pada penelitian ini, ukuran sampel berjumlah 100 responden.

Teknik pengambilan sampel dilakukan dengan metode non probability sampling dengan teknik accidental sampling. Accidental sampling adalah sampel yang diambil dari siapa saja yang kebetulan ada karena sampel ini sama sekali tidak representative 
Jurnal Kebidanan Harapan Ibu Pekalongan

tentu saja tak mungkin diambil satu kesimpulan yang bersifat generalisasi metode ini sangat mudah, murah dan cepat untuk dilakuakan $^{3]}$

Pada penelitian ini, alat pengumpulan data yang akan digunakan berupa pertanyaan dalam angket dengan mengacu pada landasan teori.

Pertanyaan dalam penelitian ini dibuat oleh peneliti dengan tinjauan pustaka yang mengacu pada landasan teori kepuasan SERVQUAL oleh Parasuraman et al. (1998) yang di modifikasi dengan kuesioner penelitian yang terkait dengan kepuasa pasien

\section{Hasil dan Pembahasan}

a) Gambaran Kepuasan Pasien Pengukuran tingkat kepuasan pasien dilakukan dengan menjumlahkan hasil pada dimensi tangibles, reliability, assurance dan empathy dengan menggunakan skor gap. Sehingga dapat dilihat nilai kualitas pelayanan sevara keseleruhan. Berikut adalah grafik yang dapat menggambarkan tingkat kepuasan posdalu di puskesmas Jenggot Kota Pekalongan.

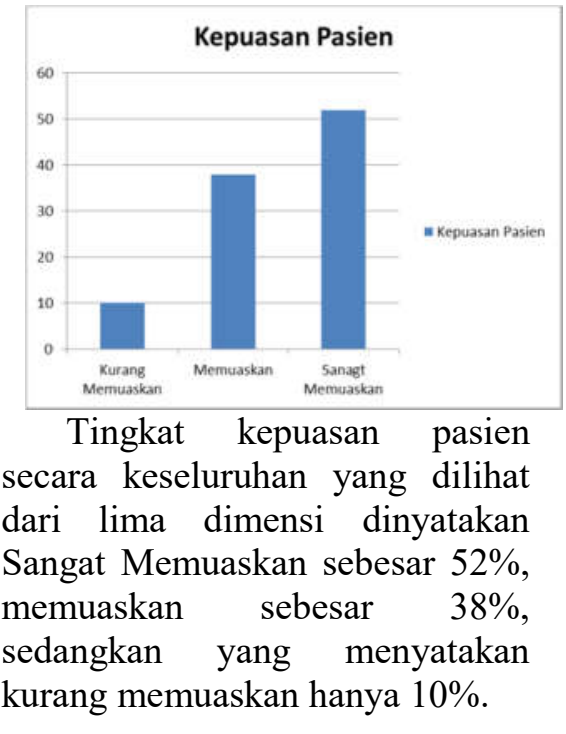

b) Gambaran Kepuasan Pasien berdasarkan Dimensi Tangibles

Gambaran tingkat kepuasan pada dimensi tangibles di Puskesmas Jenggot dilihat dari penilaian kepuasan pasien terhadap kualitas pelayanannya.

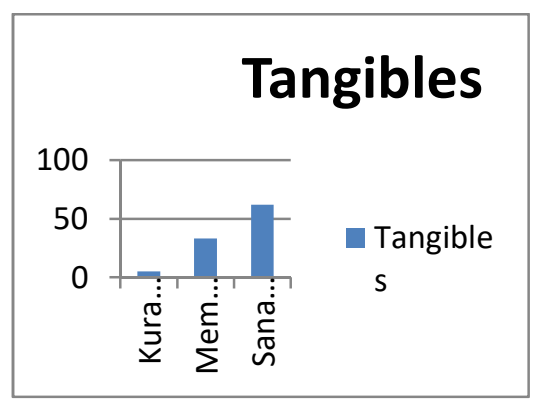

Tingkat kepuasan pasien pada dimensi tangibles dinyatakan sangat memuaskan $62 \%$, sedangkan yang menyatakan memuaskan hanya $33 \%$ dan kurang memuaskan sebesar $5 \%$.

c) Kepuasan pasien berdasarkan dimensi Reliability

Pengkajian dimensi reliability di Puskesmas Jenggot Kota Pekalongan sama seperti dimensi tangibles.

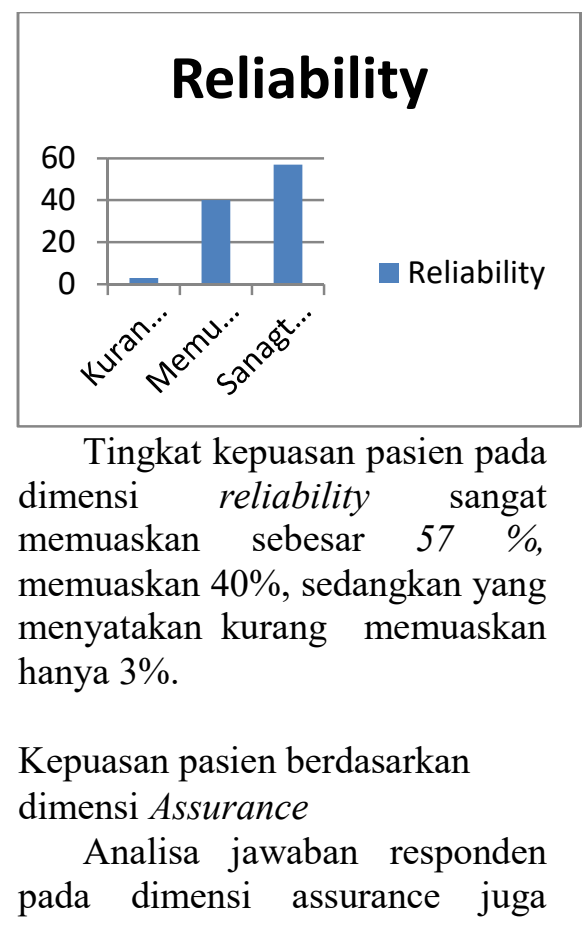


Jurnal Kebidanan Harapan Ibu Pekalongan

dilakukan pada aspek expected service dan perceived service.

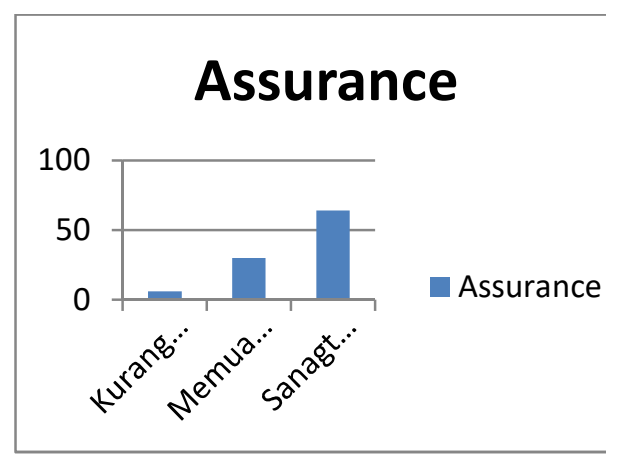

Tingkat kepuasan pasien pada dimensi assurance dinyatakan sangat memuaskan $64 \%, \quad$ sedangkan yang menyatakan memuaskan hanya $30 \%$ dan yang menyatakan kurang memuaskan $6 \%$.

e) Kepuasan pasien berdasarkan dimensi Empathy

Jawaban responden pada dimensi empathy di Puskesmas Jenggot.

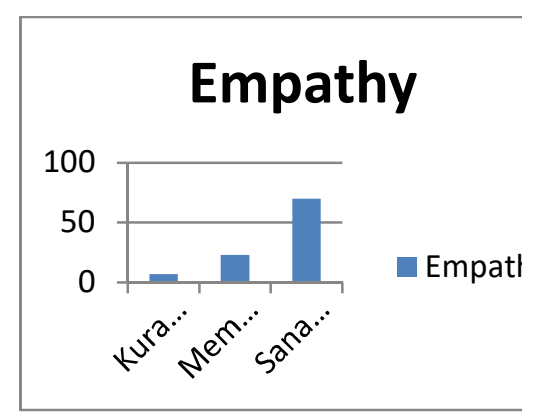

Disimpulkan bahwa tingkat kepuasan pasien pada dimensi Empaty sangat memuaskan $70 \%$ sedangkan yang menyatakan memuasakan sebesar $70 \%$ dan kurang memuaskan hanya $7 \%$.

\section{Kesimpulan}

Berdasarkan analisa jawaban 100 responden mengenai penelitian tingkat kepuasan pasien di Puskesmas Jenggot dapat dikatakan sanagt memuaskan dengan persentase $52 \%$. Hasil pengukuran persentase tingkat kepuasan pasien pada dimensi tangibles (bukti fisik) sangat memuaskan adalah $62 \%$ dari 62 responden. Dimensi realibility (kehandalan) kurang memuaskan adalah $57 \%$ dari 57 responden, dimensi assurance (jaminan) sangat memuaskan adalah $64 \%$ dari 64 responden dan dimensi empathy (empati) memuaskan adalah $70 \%$ dari 70 responden.

\section{Saran}

Perlu menggali lebih dalam tentang item-item yang kurang memuaskan menurut persepsi psien, sehingga akan lebih baik jika penelitian selanjutnya menggunakan metode kualitatif atau teknik wawancara dalam pengambilan data. Dalam pengambilan data, peneliti juga harus meyakinkan kepada calon responden tentang pentingnya penelitian dan manfaat penelitian sehingga akan meminimalisir ketidak setujuan calon responden menjadi sampel penelitian. Disamping itu, pendekatan dan komunikasi yang baik kepada responden akan mempengaruhi bagaimana responden berpartisipasi dengan baik pada penelitian.

\section{Daftar Pustaka}

[1]. Pohan, Imbalo. 2007. Jaminan Mutu Layanan Kesehatan: Dasar-dasar Pengertian dan Penerapan. Jakarta: EGC.

[2]. Sugiyono. 2012. Metode Penelitian Kuantitatif, Kualitatif dan R\&D. Bandung: Alfabeta.

[3]. Nasution. 2009. Metode research: penelitian ilmiah. Jakarta: Bumi Aksara.

[4]. Hidayat, A. Aziz Alimul. 2007. Metode penelitian Keperawatan dan Teknik Analisa Data. Jakarta: Salemba Medika. 
Jurnal Kebidanan Harapan Ibu Pekalongan

Penelitian Keperawatan dan Teknik Analisis Data. Jakarta: Salemba Medika.

[5]. Irawan, Handi. 2009. 10 Prinsip Kepuasan Pelanggan. Jakarta: Elex Media Komputindo.

[6]. Sujarweni, V. Wiratna. 2014. Panduan

Penelitian Keperawatan dengan SPSS. Yogyakarta: Pustaka Baru Press.

[7]. Puskesmas Jenggot. 2016. Profil UPT. Puskesmas
Sindangjawa Tahun 2015.

Kabupaten Cirebon:

Puskesmas Jenggot.

[8]. Wahana Komputer. 2009. Solusi Mudah dan Cepat Menguasai SPSS 17.0 untuk Pengolahan Data Statistik. Jakarta: Elex Media Komputindo

[9]. Swarjana, I ketut. 2015. Metodologi penelitian kesehatan. Yogyakarta: ANDI OFFSET. 